\title{
CLASSICAL EDUCATION, CLASSICAL LANGUAGES, CLASSICAL STUDIES
}

\begin{abstract}
The Republic of North Macedonia is a country with rich and unique classical antiquity heritage and more than 75 years old tradition of classical languages and classical culture studies at all levels of education. Nevertheless, it is evident that the interest in enrolling in the Institute of Classical Studies has been decreasing for several years already.

Different factors may be responsible for this. The present article presents and analyses the data from the survey conducted with fourth-year High school-Gymnasium students in the Republic of North Macedonia, whose goal was to investigate the relation between the interest in studying classical philology and the status of classical languages in high schools, the degree of awareness and perception of high school students of classical languages and classical studies as well as their motivation for choosing a particular university degree in general.

The results of the survey show that high school students' awareness, perception of the importance of classical education, and motivation for studying are in correlation with attending classical language classes, and there is an opportunity for the Institute of Classical Studies to address them directly in the future by creating appropriate policies.
\end{abstract}

Key words: Classical education, Classical languages, Classical studies

\section{Introduction}

There is a more than 75 years old tradition of classical education in terms of studying classical languages (Ancient Greek and Latin) and classical culture at all levels in the Republic of North Macedonia. ${ }^{1}$ The Institute of Classical Studies at the Faculty of Philosophy was founded in 1946 and it is the only higher education institution in the state that offers complete study programs at all three levels of study in the areas of classical philology, ancient studies, and Byzantology.

Classical languages have been taught as separate courses in the high schools with different intensities in different periods, while other aspects of

\footnotetext{
${ }^{1}$ In the period before the Second World War, when there was no education in Macedonian language available, the classical languages and classical culture were nevertheless taught in schools like Greek Male Gymnasium in Bitola (1884/85 - 1911/12) or the Roman Male Lyceum in Bitola (1880-1913), (Minov, 2017: 311-314).
} 
classical culture have been incorporated into courses such as Language and Literature, History, Philosophy, Art, etc. The existence of Classical Gymnasium on two occasions (from the second half of the 1940s until the second half of the 1950s and from the first half of the 1970s until the first half of the 1980s, Čadikovska, 1991: 235) and the existence of the Cultural occupational area within the Secondary vocational education should be noted as two educational models of secondary education where the classical languages and classical culture have been taught with more study hours and more comprehensive syllabi.

At the present moment, the course Classical language (Latin or Ancient Greek) has a status of optional course, i.e. it is included at least in one of the curricula of the Humanities, Science and Math and Language and arts areas of the Gymnasium. The course Latin language is included in the curricula for the educational profiles of Health care and Agriculture - Veterinary occupational areas. As to primary education, the course Classical culture in the European civilization is taught as an optional course in the sixth grade.

The continuous exposure of students to various topics of classical civilization during the primary and secondary education, as well as the continuous activity of the Institute of Classical Studies and in particular the continuous efforts of the association "Antika" to organize regularly the State Competition in Classical Languages and the other activities for the popularization of classics should result into a continuous interest of high school students to enroll in one of the degrees of the Institute of Classical Studies. But, this is not the case. In the last few years, the number of students has decreased dramatically, which suggests decreased interest of high school students for classical studies as well.

The reasons behind this could be various: lack of job opportunities, lack of opportunities to find a job with a good salary, lack of awareness of students and parents of the importance of classical education and job opportunities, inappropriately designed syllabi, inappropriate school books, lack of conditions to provide high-quality classes, poor educational management, lack of marketing, incompatibility of syllabi and curricula with the needs of new generations, unfavorable social ambient, etc.

In order to establish and investigate more specifically the relation between the interest in studying classical philology and the status of classical languages in high schools, the degree of awareness and perception of high school students of classical languages and classical studies as well as their motivation for choosing a particular university degree in general, we conducted a survey with fourth-year High school - Gymnasium students. A survey of this type is being conducted for the first time in our country. In the following passages, we shall present and analyze the survey results and data. 


\section{Results of the survey Classical education, Classical languages, Classical studies}

The survey was conducted in May - April 2021 as an electronic survey. A questionnaire in Macedonian or Albanian language was sent to the high schools in the Republic of North Macedonia that offer Gymnasium curricula. ${ }^{2}$ The questionnaire consists of several groups of questions. The first group of questions aims to collect the general information about the participants in the survey, the second group refers to the students' perception of the importance and role of knowing a classical language, the third refers to the students' awareness of classical studies, the fourth refers to the motivation to choose a university degree in general and the fifth to the motivation to potentially choose a university degree in classics.

In total, 363 fourth-year High school - Gymnasium students took part in the survey (providing 294 answers in Macedonian and 69 in Albanian language). Bearing in mind the total number of fourth-year high school students registered in the school year 2020/2021, the interest to participate in the survey is not high. ${ }^{3}$ But, on the other hand, the answers come from 13 cities (Skopje, Makedonska Kamenica, Kočani, Delčevo, Veles, Bitola, Ohrid, Gevgelija, Demir Kapija, Radoviš, Strumica, Negotino, Kičevo) and that provides a sufficiently wide basis for the analysis of the data.

In total, 283 participants in the survey attend school classes in the Macedonian language, 70 in Albanian, 8 in Turkish, 2 in English. ${ }^{4}$ The participants in the survey are predominantly female, $78.1 \%$ of those who provided answers to the questionnaire in Macedonian, i.e. $62.3 \%$ of those who provided answers in Albanian.

As to the percentage of students that studied or study classical language during their secondary education, it is $59.6 \%$ of those who answered the questionnaire in Macedonian and $72.5 \%$ of those who answered it in Albanian language.

The percentage of students that have participated in classical language competition is extremely low, less than $4 \%$, and only of those who responded to the survey in Macedonian. This is probably expected, because in the past 2020 due to the Covid 19 Pandemics the regular State competition in classical lan-

\footnotetext{
${ }^{2}$ The questionnaire was translated into Albanian by Besart Emini, classical philologist, employed in the High school - Gymnasium "Zef Lush Marku", to whom I am deeply grateful. I would also like to thank all other colleagues classical philologists, employees and managers in the high schools that answered to the request to conduct the survey and thus enabled this research and this paper.

${ }^{3}$ According to the data of the State Statistical Office at the beginning of the school year 2020/2021 the number of fourth year high school students is 16784 (News release dated 29.03.2021, No. 2.1.21.09).

${ }^{4}$ The results of the survey were not analysed in details regarding the ethnicity of the students, but the answers provided in Macedonian and in Albanian are presented separately because they are obtained from two separate questionnaires.
} 
guages organized by the Association of Classical Philologists "Antika" did not take place. Only the European Latin Exam ELEX Vestibulum took place, a competition that is anyway conducted only in electronic form, and is organized by "Euroclassica", the European Federation of Associations of Classical Languages and Civilization Teachers, whose member is the Association "Antika" as well.

As to questions related to the importance and role of knowing the classical language, one-third of students that provided answers to the questionnaire in Macedonian, completely or mostly agree that knowing Latin words makes studying other courses and reading and understanding easier, one-third express reservations, i.e. they cannot decide whether to agree or disagree and one third completely disagree or slightly agree. On the other hand, students that provided answers to the questionnaire in Albanian in quite lower percentage express reservations, $18.8 \%$, as to whether knowing Latin words makes studying other courses easier and $10 \%$ as to whether it makes reading and understanding easier. The perception is almost equally positive or negative with regard to the question of whether knowing Latin words makes studying other courses easier and in this case, about $42 \%$ of the participants in the survey mostly or completely agree that this is true, whereas $38 \%$ completely disagree or slightly agree. The negative perception is more obvious with regard to the question of whether knowing Latin words is useful for reading and understanding and $55 \%$ of the participants in the survey completely disagree or slightly agree that it makes it easier, whereas about $35 \%$ of the participants in the survey mostly or completely agree that it makes it easier.

The comparison of the answers to these two questions with the information whether the student studied or studies classical language shows that there is a correlation, i.e. that students who studied classical language in higher percentage mostly or completely agree that knowing Latin words makes studying other courses and reading and understanding easier and in lower percentage completely disagree or slightly agree, which can be an indication that the students are aware and are able to recognize the benefits of studying a classical language. ${ }^{5}$ See Table 1 and Table 2.

${ }^{5}$ A research made in Serbia with high school students that study Latin language points to similar conclusions (Dimitrijević, 2019: 36-37). 


\section{Table 1}

\begin{tabular}{|c|c|c|c|c|c|c|}
\hline \multirow{2}{*}{$\begin{array}{l}\text { The } \\
\text { language } \\
\text { of the ques- } \\
\text { tionnaire }\end{array}$} & $\begin{array}{l}\text { The } \\
\text { student }\end{array}$ & \multicolumn{5}{|c|}{$\begin{array}{l}\text { Answer to the question: Does knowing Latin words } \\
\text { make studying other courses easier? }\end{array}$} \\
\hline & & $\begin{array}{l}\text { Com- } \\
\text { pletely } \\
\text { disagree }\end{array}$ & $\begin{array}{l}\text { Slightly } \\
\text { agree }\end{array}$ & Undecided & $\begin{array}{l}\text { Mostly } \\
\text { agree }\end{array}$ & $\begin{array}{l}\text { Com- } \\
\text { pletely } \\
\text { agree }\end{array}$ \\
\hline \multirow{2}{*}{$\begin{array}{l}\text { Macedo- } \\
\text { nian }\end{array}$} & Yes & $10.9 \%$ & $20 \%$ & $28.5 \%$ & $29.2 \%$ & $11.4 \%$ \\
\hline & $\mathrm{No}$ & $25.2 \%$ & $21 \%$ & $42.9 \%$ & $9.2 \%$ & $1.7 \%$ \\
\hline \multirow[t]{2}{*}{ Albanian } & Yes & $20 \%$ & $12 \%$ & $20 \%$ & $38 \%$ & $10 \%$ \\
\hline & No & $15.8 \%$ & $42.1 \%$ & $15.8 \%$ & $15.8 \%$ & $10.5 \%$ \\
\hline
\end{tabular}

\section{Table 2}

\begin{tabular}{|l|l|l|l|l|l|l|}
\hline $\begin{array}{l}\text { The lan- } \\
\text { guage of } \\
\text { the ques- } \\
\text { tionnaire }\end{array}$ & $\begin{array}{l}\text { The } \\
\text { student } \\
\text { studied } \\
\text { or studies } \\
\text { classical } \\
\text { language }\end{array}$ & \multicolumn{5}{|l|}{$\begin{array}{l}\text { Answer to the question: Does knowing Latin words } \\
\text { make reading and understanding easier? }\end{array}$} \\
\hline & & $\begin{array}{l}\text { Com- } \\
\text { pletely } \\
\text { disagree }\end{array}$ & $\begin{array}{l}\text { Slightly } \\
\text { agree }\end{array}$ & $\begin{array}{l}\text { Unde- } \\
\text { cided }\end{array}$ & $\begin{array}{l}\text { Mostly } \\
\text { agree }\end{array}$ & $\begin{array}{l}\text { Com- } \\
\text { pletely }\end{array}$ \\
& & $12.6 \%$ & $17.7 \%$ & $35.4 \%$ & $18.8 \%$ & $15.5 \%$ \\
\hline \multirow{2}{*}{$\begin{array}{l}\text { Macedo- } \\
\text { nian }\end{array}$} & Yes & $22.7 \%$ & $30.2 \%$ & $32.8 \%$ & $11.8 \%$ & $2.5 \%$ \\
\cline { 2 - 7 } & No & $12 \%$ & $40 \%$ & $10 \%$ & $20 \%$ & $18 \%$ \\
\hline Albanian & Yes & $42.2 \%$ & $21 \%$ & $10.6 \%$ & $15.8 \%$ & $10.5 \%$ \\
\cline { 2 - 7 } & No & & & & & \\
\hline
\end{tabular}

Regarding the question of whether knowing the Latin language is essential for studying various disciplines, the results show that students recognize the role and importance of knowing Latin only in the case of medicine, and therefore $55 \%$ of the students that answered the survey in Macedonian and 48 $\%$ of those who answered it Albanian responded that knowing Latin is very important or absolutely essential for studying medicine. Unfortunately only $21 \%$ of those who provided their answers in Macedonian and $13 \%$ of those who provided answers in Albanian agree that knowing Latin is very important or absolutely essential for studying law. Students relate positively the Latin language to a greater degree to natural sciences than to humanities and social sciences. 
Therefore, $42 \%$ of those who responded to the survey in Macedonian, think that knowing Latin is very important or absolutely essential for natural sciences, whereas only $22 \%$ think it is for humanities and social sciences. Similarly, 34 $\%$ of the students who responded to the survey in Albanian think that knowing Latin is very important or absolutely essential for studying natural science, whereas only $25 \%$ think it is so for humanities and social sciences. One-third or $30 \%$ of students who provided their answers in Macedonian and $19 \%$ of the students who provided their answers in Albanian recognize the importance of knowing Latin (as very important or absolutely essential) for studying Romance languages. A very low percentage of the students, 4-6\% are aware of the importance of knowing Latin for studying Albanian. Finally, a surprisingly low percentage of the students relate knowing Latin to studying Ancient literature, and only $37 \%$ of those who answered the questionnaire in Macedonian and 18 $\%$ of those who answered it Albanian consider it as very important or absolutely essential.

The comparison of the data shows that the answers to this question can not be related in a clear way to the information whether the student studied a classical language. For example, $45.8 \%$ of those who studied and $45.4 \%$ of those who did not and answered the questionnaire in Macedonian think that it is absolutely essential to know Latin for studying medicine, whereas $57.8 \%$ of those who did not study and $28 \%$ of those who studied classical language and answered the questionnaire in Albanian gave the same answer. This could indicate that students have formed their opinion that the Latin language is important for studying a particular discipline in a way that has nothing to do with attending classes of classical language.

With regard to the awareness of the students of the possibilities for studying classical languages and ancient literature, slightly less than half of the participants in the survey that responded to it in Macedonian, i.e $46.2 \%$ answered that it is possible to study classical languages and ancient literature in Macedonia, but only one third, $33.6 \%$ know or expect that there is an appropriate degree at the Faculty of Philosophy. Two-thirds are badly informed about this matter, i.e. they make the wrong presumption or have an expectation, therefore $55.8 \%$ answered that an appropriate degree should be found at the Faculty of Philology "Blaže Koneski", and 10.6 \% at the Faculty of Pedagogy, "St. Clement of Ohrid". Similarly, slightly less than half of the participants in the survey that responded to it in Albanian, i.e 44.9\% gave a positive answer to the question of whether it is possible to study classical languages and ancient literature in Macedonia, whereas only one third, $34.8 \%$ expect that such a degree should be found at the Faculty of Philosophy.

The comparison of the answers to this question with the information whether the student studied or studies classical language shows that there is a relation between attending classes in classical language and the awareness of the possibilities for studying at the Institute of Classical Studies. See Table 3. 


\section{Table 3}

\begin{tabular}{|l|l|l|l|l|}
\hline $\begin{array}{l}\text { The language } \\
\text { of the } \\
\text { questionnaire }\end{array}$ & $\begin{array}{l}\text { The student } \\
\text { studied } \\
\text { or studies } \\
\text { classical } \\
\text { language }\end{array}$ & \multicolumn{3}{|l|}{$\begin{array}{l}\text { Answer to the question: Can you study } \\
\text { Classical languages (Latin and Ancient } \\
\text { Greek) in the Republic of North Macedonia? }\end{array}$} \\
\hline & & Yes & No & Not sure \\
\hline Macedonian & Yes & $49.1 \%$ & $5.7 \%$ & $45.2 \%$ \\
\cline { 2 - 5 } & No & $42.8 \%$ & $12.7 \%$ & $44.5 \%$ \\
\hline Albanian & Yes & $54 \%$ & $8 \%$ & $38 \%$ \\
\cline { 2 - 5 } & No & $21.1 \%$ & $31.5 \%$ & $47.4 \%$ \\
\hline
\end{tabular}

The last question in this group of questions refers to the awareness of possible employment with a degree in classics. To the greatest degree, i.e. twothirds of the participants in the survey are convinced that with a degree in classics you can work in a school. In great measure (63\% of those who answered the questionnaire in Macedonian and $49 \%$ of those who answered it in Albanian) believe that a job in a museum is an option. One-third of the participants in the survey assumes that with a degree in classics you can work in an archive. As to the possible employment in a library, one-third of those who provided their answers in Macedonian and less, $16 \%$ of those who provided their answers in Albanian gave a positive response. To a great extent, students gave a positive answer as to the possible employment in a research institute, $46 \%$ of those who responded to the survey in Macedonian and $36 \%$ of those who responded to it in Albanian. Only a small percentage of the students, less than $10 \%$ perceive media, marketing agencies, administration, banks, or law firms as possible places where you can work with a degree in classics. The results of the survey show that the students perceive university degrees in classical philology as degrees that provide narrowly specialized qualifications and competencies. Such attitudes of the students correspond to the Macedonian reality. Differently from what is common in Macedonia, in the European countries, and in the USA, a university degree in classics is the usual preparatory degree for studying law, knowing Latin is a prerequisite for enrolling in many university degrees, and in general it is normal that classics graduates find employment in banks, law offices, marketing agencies. Accordingly, the universities develop their marketing campaigns and admission policies.

A very high percentage of the participants in the survey, $80 \%$, have already decided to study and to a great extent, they have made a decision what to study, about $60 \%$. Correspondingly, $82 \%$ of those who responded to the survey in Macedonian and $75.4 \%$ of those who responded to the survey in Albanian answered that they are looking at different curricula to obtain information relevant for their choice. Although about $40 \%$ of the students have not decided yet what to study i.e. they are still considering options, only $20.3 \%$ of those who answered the questions in Macedonian and $24.6 \%$ of those who provided 
answers in Albanian, responded affirmatively that they would like to receive information about the curricula of the Institute of Classical Studies. The negative answer gave more than half of the participants in the survey, $52.9 \%$ and $53.6 \%$ accordingly. But, the comparison of the answers to the question of whether the student has decided what to study and whether he/she would like to receive information about the curricula of the Institute of Classical Studies shows that there are interested students to receive information about the curricula among those who have already decided what to study just as there are among those who have not made such a decision yet. See Table 4 .

The comparison of the results also shows that there is a clear correlation between the information whether the student studied or studies classical language and the percentage of positive and negative answers to the question of whether the student would like to receive information about the curricula of the Institute of Classical Studies. See Table 5.

\section{Table 4}

\begin{tabular}{|l|l|l|l|l|}
\hline $\begin{array}{l}\text { The lan- } \\
\text { guage of } \\
\text { the ques- } \\
\text { tionnaire }\end{array}$ & $\begin{array}{l}\text { Answer to the } \\
\text { question: Have you } \\
\text { decided what to } \\
\text { study? }\end{array}$ & \multicolumn{3}{|l|}{$\begin{array}{l}\text { Answer to question: Would you like to } \\
\text { receive information about the curricula of the } \\
\text { Institute of Classical Studies? }\end{array}$} \\
\hline & Yes & Yes & No & Not sure \\
\hline & No & $20.4 \%$ & $56.9 \%$ & $22.7 \%$ \\
\cline { 2 - 5 } & Still thinking & $8.7 \%$ & $69.5 \%$ & $21.8 \%$ \\
\hline \multirow{4}{*}{ Macedonian } & & $24.2 \%$ & $40.4 \%$ & $35.4 \%$ \\
\hline & Yes & & & \\
\cline { 2 - 5 } & No & $15.5 \%$ & $66.6 \%$ & $17.9 \%$ \\
\cline { 2 - 5 } & Still thinking & $35 \%$ & $50 \%$ & \\
\hline \multirow{4}{*}{ Albanian } & & & $35.7 \%$ & $28.6 \%$ \\
\hline
\end{tabular}

\section{Table 5}

\begin{tabular}{|l|l|l|l|l|}
\hline $\begin{array}{l}\text { The lan- } \\
\text { guage of the } \\
\text { question- } \\
\text { naire }\end{array}$ & $\begin{array}{l}\text { The student } \\
\text { studied } \\
\text { or studies } \\
\text { classical } \\
\text { language }\end{array}$ & \multicolumn{3}{|l|}{$\begin{array}{l}\text { Answer to the question: Would you like to } \\
\text { receive information about the curricula of the } \\
\text { Institute of Classical Studies? }\end{array}$} \\
\hline & & \multicolumn{3}{|l|}{} \\
\hline & Yes & $22.3 \%$ & $48 \%$ & $29.7 \%$ \\
\cline { 2 - 5 } & No & $18.5 \%$ & $58.8 \%$ & $22.7 \%$ \\
\hline
\end{tabular}




\begin{tabular}{|l|l|l|l|l|}
\hline \multirow{3}{*}{ Albanian } & Yes & $30 \%$ & $46 \%$ & $24 \%$ \\
\cline { 2 - 5 } & No & $10.5 \%$ & $73.7 \%$ & $15.8 \%$ \\
\hline
\end{tabular}

As to the motivation of the students for choosing a university degree i.e. their expectations about the curricula, the participants in the survey with small exceptions evaluate in a similar way the acquisition of knowledge in the area of interest, a diploma that guarantees employment, a job with a good salary, acquisition of competencies, skills, and attitudes, opportunities for personal development and opportunities for socialization (See Table 6). To the greatest degree, they think that it is very important or absolutely essential that a university degree enables all these benefits. The percentages are as high as $63-69 \%$ for the students that answered the questionnaire in Macedonian. A closer look at the data reveals that acquisition of knowledge in the area of interest comes first, and socialization is least important. The percentages for the students that answered the questionnaire in Albanian show wider fluctuation, 35-46 \% and it is obvious that these students consider an acquisition of knowledge in the area of interest and acquisition of competencies, skills, and attitudes equally important or most important, and the socialization least important.

What is probably most interesting for the Institute of Classical Studies is whether students would enroll in Classics degree if this degree can fulfill their expectations, i.e. if it enables them to acquire acquisition of knowledge in the area of interest, if it guarantees employment, a job with a good salary if it enables the acquisition of competences, skills, and attitudes that can be applied in practice and in a professional context and enables their personal development and socialization. The survey reveals that the highest percentage of the students agree mostly or completely i.e. would enroll in a classics degree if the above-mentioned expectations are fulfilled. The percentages are $44-62 \%$ for the students that provided their answers in Macedonian and $32-49 \%$ for the students that provided their answers in Albanian. Still, the comparison of the results shows (see Table 6) that the percentage of students that agree mostly or completely to enroll in a classics degree is lower than the percentage of students who think that it is very important or absolutely essential that the university degree in which they would enroll fulfills particular expectations, i.e. enables them certain benefits. The differences are greater for the answers in Macedonian than for the answers in Albanian. The reasons for this should be investigated in additional more detailed research. 


\section{Table 6}

\begin{tabular}{|c|c|c|}
\hline $\begin{array}{l}\text { The lan- } \\
\text { guage of } \\
\text { the ques- } \\
\text { tionnaire }\end{array}$ & $\begin{array}{l}\text { Answer to the question: Is it / } \\
\text { how much it is important to you } \\
\text { the university degree that you } \\
\text { will choose }\end{array}$ & $\begin{array}{l}\text { Answer to the question: Do } \\
\text { you agree with the statement } \\
\text { I would enroll in a classics } \\
\text { degree }\end{array}$ \\
\hline & $\begin{array}{l}\text { To enable you to acquire } \\
\text { knowledge from the area of your } \\
\text { interest }\end{array}$ & $\begin{array}{l}\text { If that is what I am most } \\
\text { interested in }\end{array}$ \\
\hline & Not important at all & Completely disagree \\
\hline Macedonian & $3 \%$ & $7.9 \%$ \\
\hline \multirow[t]{2}{*}{ Albanian } & $6 \%$ & $17.6 \%$ \\
\hline & Slightly important & Slightly agree \\
\hline Macedonian & $5 \%$ & $10.7 \%$ \\
\hline \multirow[t]{2}{*}{ Albanian } & $13 \%$ & $23.5 \%$ \\
\hline & Undecided & Undecided \\
\hline Macedonian & $25 \%$ & $19.7 \%$ \\
\hline \multirow[t]{2}{*}{ Albanian } & $35 \%$ & $16.2 \%$ \\
\hline & Very important & Mostly agree \\
\hline Macedonian & $8.5 \%$ & $21.7 \%$ \\
\hline \multirow[t]{2}{*}{ Albanian } & $3 \%$ & $10.3 \%$ \\
\hline & Absolutely essential & Completely agree \\
\hline Macedonian & $58.5 \%$ & $40 \%$ \\
\hline \multirow[t]{3}{*}{ Albanian } & $43 \%$ & $32.4 \%$ \\
\hline & To guarantee you employment & $\begin{array}{l}\text { If that guarantees me } \\
\text { employment }\end{array}$ \\
\hline & Not important at all & Completely disagree \\
\hline Macedonian & $3.7 \%$ & $16.2 \%$ \\
\hline \multirow[t]{2}{*}{ Albanian } & $7.2 \%$ & $17.4 \%$ \\
\hline & Slightly important & Slightly agree \\
\hline Macedonian & $6 \%$ & $9.3 \%$ \\
\hline \multirow[t]{2}{*}{ Albanian } & $19 \%$ & $26.1 \%$ \\
\hline & Undecided & Undecided \\
\hline Macedonian & $24 \%$ & $24.4 \%$ \\
\hline \multirow[t]{2}{*}{ Albanian } & $33.3 \%$ & $15.9 \%$ \\
\hline & Very important & Mostly agree \\
\hline Macedonian & $14.3 \%$ & $22.3 \%$ \\
\hline \multirow[t]{2}{*}{ Albanian } & $8.6 \%$ & $21.7 \%$ \\
\hline & Absolutely essential & Completely agree \\
\hline Macedonian & $52 \%$ & $27.8 \%$ \\
\hline \multirow[t]{3}{*}{ Albanian } & $31.9 \%$ & $18.8 \%$ \\
\hline & $\begin{array}{l}\text { To guarantee you job with a } \\
\text { good salary }\end{array}$ & $\begin{array}{l}\text { If that guarantees me job with } \\
\text { a good salary }\end{array}$ \\
\hline & Not important at all & Completely disagree \\
\hline
\end{tabular}




\begin{tabular}{|c|c|c|}
\hline Macedonian & $3 \%$ & $13.4 \%$ \\
\hline \multirow[t]{2}{*}{ Albanian } & $4.3 \%$ & $11.6 \%$ \\
\hline & Slightly important & Slightly agree \\
\hline Macedonian & $5.1 \%$ & $6.2 \%$ \\
\hline \multirow[t]{2}{*}{ Albanian } & $24.7 \%$ & $10.1 \%$ \\
\hline & Undecided & Undecided \\
\hline Macedonian & $28 \%$ & $19.7 \%$ \\
\hline \multirow[t]{2}{*}{ Albanian } & $26.1 \%$ & $29 \%$ \\
\hline & Very important & Mostly agree \\
\hline Macedonian & $14.6 \%$ & $25.9 \%$ \\
\hline \multirow[t]{2}{*}{ Albanian } & $7.2 \%$ & $21.7 \%$ \\
\hline & Absolutely essential & Completely agree \\
\hline Macedonian & $49.3 \%$ & $34.8 \%$ \\
\hline \multirow[t]{3}{*}{ Albanian } & $37.7 \%$ & $27.5 \%$ \\
\hline & $\begin{array}{l}\text { To enable you to acquire } \\
\text { competences, skills and attitudes }\end{array}$ & $\begin{array}{l}\text { If that enables me to acquire } \\
\text { competences and skills that can } \\
\text { be applied in practice and in } \\
\text { professional context }\end{array}$ \\
\hline & Not important at all & Completely disagree \\
\hline Macedonian & $4 \%$ & $11.7 \%$ \\
\hline \multirow[t]{2}{*}{ Albanian } & $8.7 \%$ & $10.1 \%$ \\
\hline & Slightly important & Slightly agree \\
\hline Macedonian & $7.5 \%$ & $10.3 \%$ \\
\hline \multirow[t]{2}{*}{ Albanian } & $20.3 \%$ & $24.6 \%$ \\
\hline & Undecided & Undecided \\
\hline Macedonian & $24.2 \%$ & $27.1 \%$ \\
\hline \multirow[t]{2}{*}{ Albanian } & $24.6 \%$ & $30.4 \%$ \\
\hline & Very important & Mostly agree \\
\hline Macedonian & $11.2 \%$ & $24.1 \%$ \\
\hline \multirow[t]{2}{*}{ Albanian } & $10.1 \%$ & $17.4 \%$ \\
\hline & Absolutely essential & Completely agree \\
\hline Macedonian & $53 \%$ & $26.8 \%$ \\
\hline \multirow[t]{3}{*}{ Albanian } & $36.3 \%$ & $17.4 \%$ \\
\hline & $\begin{array}{l}\text { To enable your personal } \\
\text { development }\end{array}$ & $\begin{array}{l}\text { If that enables my personal } \\
\text { development }\end{array}$ \\
\hline & Not important at all & Completely disagree \\
\hline Macedonian & $3 \%$ & $11.7 \%$ \\
\hline \multirow[t]{2}{*}{ Albanian } & $7.2 \%$ & $15.9 \%$ \\
\hline & Slightly important & Slightly agree \\
\hline Macedonian & $7 \%$ & $11.3 \%$ \\
\hline \multirow[t]{2}{*}{ Albanian } & $17.4 \%$ & $18.8 \%$ \\
\hline & Undecided & Undecided \\
\hline Macedonian & $26 \%$ & $30.2 \%$ \\
\hline
\end{tabular}




\begin{tabular}{|l|l|l|}
\hline Albanian & $30.4 \%$ & $21.7 \%$ \\
\hline & Very important & Mostly agree \\
\hline Macedonian & $12 \%$ & $16.8 \%$ \\
\hline Albanian & $8.7 \%$ & $21.7 \%$ \\
\hline & Absolutely essential & Completely agree \\
\hline Macedonian & $52 \%$ & $29.9 \%$ \\
\hline Albanian & $36.3 \%$ & $21.7 \%$ \\
\hline & To enable your socialization & If that enables my socialization \\
\hline & Not important at all & Completely disagree \\
\hline Macedonian & $4 \%$ & $14.5 \%$ \\
\hline Albanian & $11.6 \%$ & $13 \%$ \\
\hline & Slightly important & Slightly agree \\
\hline Macedonian & $8 \%$ & $15.6 \%$ \\
\hline Albanian & $18.8 \%$ & $23.2 \%$ \\
\hline & Undecided & Undecided \\
\hline Macedonian & $25 \%$ & $26 \%$ \\
\hline Albanian & $34.8 \%$ & $31.9 \%$ \\
\hline & Very important & Mostly agree \\
\hline Macedonian & $16 \%$ & $15.9 \%$ \\
\hline Albanian & $10.1 \%$ & $14.5 \%$ \\
\hline & Absolutely essential & Completely agree \\
\hline Macedonian & $47 \%$ & $28 \%$ \\
\hline Albanian & $24.6 \%$ & $17.4 \%$ \\
\hline
\end{tabular}

\section{Conclusion}

The analysis of the data shows that the students in the greater degree are not sufficiently aware of the importance and role of knowing Latin words for studying other courses and reading and understanding in general, as well as for studying various disciplines. But, those who have studied classical language by a higher percentage have a positive perception, i.e. agree mostly or completely that knowing Latin words makes studying other courses and reading and understanding easier. The perception of the students of the importance of knowing Latin for studying, including disciplines such as ancient literature can not be related in a clear way with the fact whether the student attended or not classical language classes.

The survey confirms that students are not sufficiently well informed about the possibilities for studying classical languages and ancient literature, i.e. that two-thirds of them make the wrong assumption as to which faculty offers a degree in classics. However, the comparison shows those who studied or study classical language are well informed to a greater degree. The results from the survey indicate that the students perceive the university degrees in classical philology as degrees that provide narrowly specialized qualifications and 
competencies and do not expect such diplomas to provide them employment outside of the sphere of education and culture.

To the highest degree, the participants in the survey have already decided to study and what to study, correspondingly, only $20-25 \%$ confirmed that they would like to receive information about the curricula of the Institute of Classical Studies. The research shows that with regard to this once again attending classical language classes makes difference. And probably of greatest importance is the fact the affirmative answers come from those who have already decided what to study just as they come from those who are still considering options. Students evaluate in a similar way the acquisition of knowledge in the area of interest, a diploma that guarantees employment, a job with a good salary, acquisition of competencies, skills, and attitudes, opportunities for personal development, and opportunities for socialization i.e. they think to the greatest degree, that all these are very important or absolutely essential for the choice of a university degree. Although, in a slightly lower percentage, the students would enroll in a classics degree if this degree is what they are most interested in or if this degree could fulfill the above-mentioned expectations.

Having in mind the survey results it is obvious that there is an opportunity for the Institute of Classical Studies to create appropriate policies and to carry out particular activities that would improve the status of the classical languages in secondary education and create more versatile opportunities for making high school students aware of the curricula of the Institute, of the job opportunities for the graduates, as well as of the importance and role of classical education in general. 


\section{References:}

Минов, Н. (2017). Гимназиите во османдиска Македонија. Во В., Ѓорѓиев и др., уред., 70 години Институт за историја. 70 години македонска историографија. Зборник на трудови од научната конференција одржана на 13 и 14 декември 2016 во Скопје. Скопје: УКИМ / ФЗФ, стр. 305-345.

Чадиковска, Д. (1991). Класичното образование во СР Македонија. Во: П. Хр. Илиевски и В. Митевски, уред., Грчко-римска антика во Југославија и на Балканот. Прилози од 5-иот Научен собир на Сојузот на друштвата за антички студии на Југославија, одржан во Скопје од 26 до 29 септември 1989 г. ЖА Посебни изданија бр. 9, стр. 234-239.

Canfarotta, D. et al. (2018). Digital competences and teaching of classical languages: student's perception in Italian and Spanish schools. In: F. J. García-Peñalvo, ed., Proceedings of 6th International Conference Technological Ecosystems for Enhancing Multiculturality, (Salamanca, Spain, October 2426, 2018). New York, NY: ACM, 5 pages.

Dimitrijević, D. (2019). Latin curricula, Attitudes and Achievement: An Empirical Investigation. Во: В. Димовска-Јањатова и Д. Тошева-Николовска, уред., Exegi monumentum aеre perennius. Зборник во чест на Eлена Колева, Љубинка Басотова и, Даница Чадиковска, по повод 85 години од нивното раѓaнье. Систасис Посебно издание 5, стр. 27-42. 